\title{
EPIDEMIOLOGICAL DETERMINANTS OF Chrysomya (Diptera: Calliphoridae) INFESTATION IN LAYER FARMS OF MINAS GERAIS, BRAZIL
}

\author{
DETERMINANTES EPIDEMIOLÓGICOS DA INFESTAÇÃO POR Chrysomya \\ (Diptera: Calliphoridae) EM GRANJAS AVÍCOLAS DE POSTURA DE MINAS \\ GERAIS, BRASIL
}

\begin{abstract}
Leandro do Carmo REZENDE ${ }^{1}$; Tiago Mendonça de OLIVEIRA ${ }^{2}$; Cristina Mara TEIXEIRA ${ }^{3}$; Nelson Rodrigo da Silva MARTINS ${ }^{2}$; Marcos Xavier SILVA ${ }^{2}$; Paulo Roberto de OLIVEIRA ${ }^{2 \dagger}$ Lucas Maciel CUNHA ${ }^{4}$.

1. Ministry of Agriculture, Livestock and Supply (LFDA/MG), Pedro Leopoldo, MG, Brazil; 2. Department of Preventive Veterinary Medicine, Veterinary School, Federal University of Minas Gerais, Belo Horizonte, Minas Gerais, Brazil († in memorian) tiago0725@gmail.com; 3. Ministry of Agriculture, Livestock and Supply (DIPOA), Brasília, DF, Brazil; 4. Ezequiel Dias Foundation, Belo Horizonte, MG, Brazil.
\end{abstract}

\begin{abstract}
Aspects related to the epidemiology of Diptera belonging to genus Chrysomya were studied in order to determine predisposing factors for their occurrence in commercial laying hens farms from the state of Minas Gerais, Brazil. An observational, analytical and sectional survey was conducted to verify the main epidemiological determinants of infestations by Chrysomya spp. Forty-three farms were visited in 2012 and these 13 (30,23\%) were infested by Chrysomya putoria, 4 (9,30\%) by Chrysomya megacephala and 2 (4,65\%) by Chrysomya albiceps and in 2 farms $(4,65 \%)$ was not possible to identify the species of Chrysomya. The epidemiological determinants for the occurrence of infestations by Chrysomya spp. were investigated using multiple logistic regression models. Housing clustering type and its conditions were important factors involved in epidemiology of these species $(\mathrm{OR}=5.05,95 \% \mathrm{CI}=2.66$ to $9.58, \mathrm{p}=0.000)$. It was also observed that the increase of the humidity of manure leads to increase chances of infestations $(\mathrm{OR}=1.81,95 \% \mathrm{CI}=1.36$ to 2.40 , $\mathrm{p}=0.000)$. The presence of the beetle "lesser mealworm" (Alphitobius diaperinus $)(\mathrm{OR}=0.15,95 \% \mathrm{CI}=0.067$ to $0.36, \mathrm{p}=0.000$ ) was characterized as a protective factor against infestations, probably due to predation behavior of the beetle. Some regions of the state were characterized as lower risk areas for Chrysomya spp. infestation as compared to other regions. Management measures, such as constant monitoring of water leaks on manure, adequate composting of dead poultry and periodic removal of manure could assist in decreasing the presence of Chrysomya spp. inside the laying houses.
\end{abstract}

KEYWORDS: Chrysomya putoria. Chrysomya megacephala. Chrysomya albiceps. Laying hen. Poultry manure management. Epidemiological determinants.

\section{INTRODUCTION}

The characteristics of systems of laying hens breeding in brazilian poultry farms lead to accumulation of manure, which is an excellent substrate for the development of synanthropic flies (LOPES et al., 2008). Flies use the food debris, dead animals, broken eggs and accumulated manure to survive (NUORTEVA, 1963; PECK; ANDERSON, 1970; PRADO, 2003). Muscoid diptera are considered important vectors of pathogens for humans and other animals, due their eating, reproductive and synanthropic behavior. Moreover, those arthropods have ability to movement and fly long distances (BARREIRO et al., 2013; BLAAK et al., 2014).
Flies belonging to the genus Chrysomya (Diptera: Calliphoridae) (Robineau-Desvoidy, 1830) are important diptera for human and other animal health, since they have potential to carrier several pathogens (YANG, et al. 2019). The species Chrysomya megacephala (Fabricius, 1794), known as 'oriental latrine blowfly' and Chrysomya putoria (Wiedemann, 1830), also known as 'african latrine blowfly', have been reported in environments associated with poultry production in Brazil (MONTEIRO; PRADO, 2000; LOPES et al., 2007).

There are few studies about the biology, ecology and predisposing factors of these arthropods in laying hens farms and of factors related to the epidemiology of infestations. Borges (2006) reported that the presence of synanthropic flies causes health problems for chickens and possible 
economic damages to the poultry farms. Then, it is important to invest in epidemiological studies that can evaluate the predisposing factors for the presence of synanthropic flies in poultry systems. These studies may assist the implementation of measures to control more efficiently the infestations of flies in laying hens farms. Therefore, this study aimed to determine the factors involved in the epidemiology of infestations by flies of the genus Chrysomya in poultry farms of the state of Minas Gerais, Brazil.

\section{MATERIAL AND METHODS}

\section{Geographic area}

The study was conducted in commercial layer farms in the state of Minas Gerais, Brazil. From March to June 2012, 431 layer chicken houses were visited in 43 farms. The selection of farms and stratification of the samples were performed considering the proportion of commercial laying poultry farms in the 20 administrative regions of Instituto Mineiro de Agropecuária (IMA). A map with these regions was showed previously by Rezende et al. (2015) and Rezende et al. (2018). The state of Minas Gerais is located in the southeastern region of Brazil and has an area of 586.521,121 $\mathrm{km}^{2}$, characterized by the large range of climatic conditions (IBGE, 2019).

\section{Sampling}

The inspection of poultry facilities was performed, and samples of manure, flies and other arthropods were collected. Samples were packed in airtight plastic bags, refrigerated and routed to the Ectoparasitosis Laboratory of Veterinary Medicine School of the Federal University of Minas Gerais (UFMG), where they were stored at $-20 \pm 2{ }^{\circ} \mathrm{C}$ until processing. Morphological characteristics were determined in a stereoscopic microscope (Olympus, Japan). Species of the genus Chrysomya were identified as indicated previously (McALPINE et al., 1987; CARVALHO; RIBEIRO, 2000; GUIMARÃES et al., 2001; AMAT et al., 2008; TRIPLEHORN et al., 2011; RAFAEL et al., 2012).

\section{Questionnaire}

During visits to poultry establishments, a questionnaire was applied in order to obtain information related to predisposing factors for the occurrence of flies. A preliminary version of the questionnaire, containing 97 alternatives of objective and categorical questions was prepared and submitted to a test-retest validation procedure, using kappa test. Questions with reliabilities ranging from regular to excellent (kappa greater than $0.4, \mathrm{p}$ $\leq 0.05)$ or with unanimous answers were kept (LANDIS; KOCH, 1977). The final version of the questionnaire with 89 alternatives was applied and presented by Cunha (2013) and Rezende (2014). This study was approved by the ethics committees of the UFMG (COEP/UFMG Ethic Number 0238.0.203.000-11 and CETEA/UFMG 41/2011).

\section{Statistical analysis}

The simultaneous evaluation of different risk factors for the occurrence of infestations by Chrysomya spp. was performed using logistic regression models, as demonstrated by Dohoo et al. (2003). These models were constructed using the software Stata ® 12.0. The preliminary selection of variables was performed using the Chi-square test, Fisher's exact test and univariate logistic regression and the confounding variables and those with significance less than $15 \%$ ( $\mathrm{p}>0.15$ ) were removed. Variables selected by univariate statistical tests were used in multivariate logistic regression models with significant $(\mathrm{p} \leq 0.05)$. The characteristics with suspect hierarchical or clustering relation effect had the values of intra-class correlation calculated. Variables with value equal or higher than 0,40 were then subdivided into dichotomous variables (dummy variables). The selection of the highest $\mathrm{R}^{2}$ values determination coefficients and the analysis of the Odds Ratios confidence intervals (95\% significance) were also used for variable selection and construction of the models. Variables with significant Odds Ratio $(\mathrm{p} \leq 0.05)$ or whose removal would disrupt the general model were kept. The verification of model fitness was performed using the Wald's test $(\mathrm{p} \leq 0.05)$ and the HosmerLemeshow's Test ( $>>0.05)$. The check of the area under curve - ROC (Receiver Operating Characteristic) and the value of the pseudocoefficient of determination were also considered for choosing the logistic model.

\section{RESULTS}

The flies of the genus Chrysomya were the most frequent, and their presence was verified in 160 laying houses of 21 farms (48.83\%). The most abundant specie was $C$. putoria, which was found in $30.23 \%$ of farms, followed by C. megacephala, which occurred in almost $10 \%$ of the farms. Chrysomya albiceps (Wiedemann, 1819) was the most uncommon specie of this genus, and it presence was verified only in two farms $(4.65 \%)$.

Table 1 show selected characteristics in screening tests performed using the Chi-square, 
Fisher's exact test and univariate logistic regression. The regions where are located each poultry farm, which was considered a priori as a variable hierarchically associated with the occurrence of Chrysomya spp., presented high values of intra-class correlation $(73.76 \%)$. Thus, this variable was decomposed (creating dummy variables) and these areas were evaluated individually.

Preliminary logistic models were built for selection of variables. The use of mechanical removal of manure $(\mathrm{p}=0.084)$, the type of establishment $(\mathrm{p}=0.201)$, the use of selective insecticides $(p=0.267)$, the existence of biological control $(\mathrm{p}=0.880)$, the presence of beetles of the genus Dichotomius ( $\mathrm{p}=0.380$ ), the occurrence of Uropodidae mites in manure of the layer chicken houses $(\mathrm{p}=0.399)$ and the interval of manure removal $(p=0.312)$ lost significance and were removed from the general model.

Table 1. Characteristics potentially associated with the occurrence of infestations by Chrysomya spp. selected by univariate statistical tests $(\mathrm{p}<0.15)$ in commercial laying poultry flocks of the state of Minas Gerais, Brazil, 2012.

\begin{tabular}{ll}
\hline Characteristic & p value \\
\hline Region & 0.000 \\
$\begin{array}{l}\text { Chicken house cluster } \\
\text { Type of establishment } \\
\text { (Laying with mechanical removal or with manual removal, Replacement pullets or meat } \\
\text { poultry) }\end{array}$ & 0.000 \\
Removal of manure & 0.000 \\
Humidity of manure & 0.000 \\
Manure removal interval & 0.000 \\
Number of chickens by cage (Density of hens) & 0.000 \\
Use of selective insecticides to flies combat & 0.000 \\
Mechanical removal of manure & 0.000 \\
Existence of biological control & 0.000 \\
Fumigation of the layer chicken houses with chemicals substances & 0.065 \\
Presence of Alphitobius diaperinus & \\
Presence of Dermester ater & 0.097 \\
Presence of Hololepta spp. & 0.000 \\
Presence of Euspilotus spp. & 0.128 \\
Presence of Dichotomius spp. & 0.064 \\
Presence of Uropodidae mites in manure & 0.000 \\
\hline
\end{tabular}

The use of fumigation of the layer chicken houses with chemicals substances was removed from the model due to occurrence of collinearity. The presence of beetles of the genus Euspilotus (Coleoptera: Histeridae) (Lewis 1907) $(\mathrm{OR}=1.07 \mathrm{x}$ $10^{9}, 95 \% \mathrm{CI}=1.74 \times 10^{8}$ to $6.57 \times 10^{9}, \mathrm{p}=0.000$ ) and Hololepta (Coleoptera: Histeridae) (Paykull, 1811) $\left(\mathrm{OR}=3.31 \times 10^{7}, 95 \% \mathrm{CI}=6.10 \times 10^{5}\right.$ to $\left.1,85 \times 10^{9}, p=0.000\right)$ and the number of poultry per cage $(\mathrm{OR}=0.31,95 \% \mathrm{CI}=0.12$ to $0.77, \mathrm{p}=0.012)$ were considered confounders variables and were removed from the model. The presence of beetles
Dermestes ater (Coleoptera: Dermestidae) (De Geer, 1774) was removed due to non-occurrence of this species in layer chicken houses where was found Chrysomya spp.

Table 2 show the factors associated with the occurrence of Chrysomya spp. in the state of Minas Gerais. The regions of Juiz de Fora, Varginha and Viçosa were removed from the model due to nonverification of the presence of these flies in poultry farms of these regions. The regional of Unaí was removed due to occurrence of perfect success of the model, which indicates that in this region every 
layer chicken houses and farms presented

Chrysomya spp. infestations.

Table 2. Characteristics associated with the occurrence of Chrysomya spp. in commercial laying poultry flocks in state of Minas Gerais, Brazil, 2012.

\begin{tabular}{lllll}
\hline \multicolumn{1}{c}{ Characteristic } & $\begin{array}{l}\text { Odds } \\
\text { Ratio }\end{array}$ & \multicolumn{1}{c}{ Confidence Interval (95\%) } & p value \\
\hline Chicken house cluster & 5.05 & 2.66 & 9.58 & 0.000 \\
Humidity of manure & 1.81 & 1.36 & 2.40 & 0.000 \\
Presence of A. diaperinus & 0.15 & 0.067 & 0.36 & 0.000 \\
Region of de Belo Horizonte & 0.12 & 0.037 & 0.42 & 0.001 \\
Region of Oliveira & 0.06 & 0.020 & 0.17 & 0.000 \\
Region of Passos & 0.17 & 0.039 & 0.78 & 0.022 \\
Region of Pouso Alegre & 0.40 & 0.12 & 1.28 & 0.124 \\
Region of Uberaba & 0.07 & 0.022 & 0.26 & 0.000 \\
\hline
\end{tabular}

Number of valid observations: 262; Region reference for the elaboration of Odds Ratio: Bambuí; P value for goodness of fit of the model in the Wald test: <0.001; P value for goodness of fit of the model in the Hosmer-Lemeshow test: 0.5758;Model sensitivity (Probability +| Infested): 78.67\%; Model specificity (Probability -I Non-Infested): 84.82\%; Area under the curve of the Receiver Operating Characteristics (ROC-Curve Receiver Operating Characteristic): 88.25\%; Pseudo $\mathrm{R}^{2}$ (pseudo coefficient of determination): 0.3732

\section{DISCUSSION}

The occurrence of Chrysomya spp. in laying hens farms in Minas Gerais is similar to other studies conducted in Brazil. LOPES et al. (2007) noted the presence of $C$. megacephala in a poultry farm located in the state of São Paulo. AVANCINI; SILVEIRA (2000) conducted a study about flies in poultry establishments in southeastern of Brazil and found $C$. putoria and $C$. megacephala. MONTEIRO; PRADO (2000), also conducted studies in laying farms in the state of São Paulo and verified the presence of $C$. putoria. BORGES (2006), in a study conducted in a poultry farm located in Minas Gerais, observed that $C$. putoria was the most common specie of synanthropic fly.

Some variables related to manure management lost significance and were removed of model, as the mechanical removal of manure $(\mathrm{p}=$ $0.084)$ and the interval of manure removal $(\mathrm{p}=$ 0.312 ). The periodic removal of manure also was excluded from the model due to occurrence of perfect failure. However, these characteristics should be reevaluated in further studies, since the removal of manure reduces the amount of substrate available for the development of flies. In addition, it is important to emphasize that there are two strands of manure management strategies in posture aviaries in Brazil. The first is to remove these wastes in a period lesser than three days, avoiding the changing of the larvae into pupae. The other is to remove after a very long period, reducing the humidity of the manure and allowing the growth of predators, keeping the infestations in low levels. Both, if correctly used, give satisfactory results, but also may fail depending on other factors such as the presence of humidity or removal inefficiency.

The type of establishment (laying hens farm with manual removal, laying hens farm with mechanical removal and replacement chickens) also lost significance, highlighting the influence of nonautomatic removal on the occurrence of Chrysomya spp. The use of selective insecticides, the fumigation of the facilities and the verification of biological control also not remained in the general model. These results suggest that other factors are more important for the occurrence of these flies. There is also the possibility of improper application of pesticides, what would lead to inadequate control of infestations.

The variables presence of beetles Dichotomius spp. (Coleoptera: Scarabaeidae) (Hope, 1838), Dermestes ater, Euspilotus spp. and Hololepta spp. not remained in the logistic model. Due to the values of the confidence intervals of their respective odds ratios, therefore the presence of beetles of the genus Euspilotus ( $\mathrm{OR}=1.07 \times 10^{9}$; $95 \% \mathrm{CI}=1.74 \times 10^{8}$ to $\left.6.57 \times 10^{9}, \mathrm{p}=0.000\right)$ and of the genus Hololepta $\left(\mathrm{OR}=3.31 \times 10^{7} ; 95 \% \mathrm{CI}=6.10\right.$ $\mathrm{x} 10^{5}$ to $1,85 \times 10^{9}, \mathrm{p}=0.000$ ) were classified wrongly as risk factors for the occurrence of Chrysomya spp. However, there are reports of the predation of eggs 
of $C$. putoria by $E$. modestus (GIANIZELLA, 2000). Therefore, as predator, it is expected to behave as a protection factor against infestations and not as a risk factor. Then, the presence of beetles of these genus were considered confounders variables and were removed from the model. The presence of Uropodidae mites in manure $(\mathrm{p}=0.399)$ lost significance. However, some authors report that these mites are predators of Diptera (AXTELL; ARENDS, 1990). The number of hens per cage (OR $=0.31,95 \% \mathrm{CI}=0.12$ to $0.77, \mathrm{p}=0.012$ ) was characterized as a protective factor, what have not biological plausibility, leading to the exclusion of the logistic model.

Brazilian law defines as laying house a physics unit of poultry production composed of one or more sheds, which house a group of hens of the same species and age. The clusterings must have similar and appropriate management and should be isolated from other activities of poultry production through use of physical barriers (INSTRUÇÃO NORMATIVA $n^{\circ} 56$ of 04 December, 2007). These variable $(\mathrm{OR}=5.05,95 \% \mathrm{CI}=2.66$ to $9.58, \mathrm{p}=$ 0.000 ) obtained an Odds Ratio with a confidence interval that indicates that in some clustering the chances of occurrence of infestations is almost 5 times higher than in other, even if it is located in the same farm. Thus, it is suggested that intrinsic characteristics of each chicken house clustering, which were not evaluated in this study, may influence the occurrence of infestations.

The humidity of poultry manure $(\mathrm{OR}=$ $1.81,95 \% \mathrm{CI}=1.36$ to $2.40, \mathrm{p}=0.000$ ) was characterized as a predisposing factor for the occurrence of flies of the genus Chrysomya. Thus, the increase in moisture manure leads to increase in chances of infestations. The influence of humidity in populations of Diptera is also highlighted by Axtell; Arends (1990), who state that the parts of the laying houses where there are no water pipe leaks, the manure is drier and there are smaller populations of flies. Studies about other species of Diptera, such as Musca domestica (Diptera: Muscidae) (Linnaeus, 1758) have also shown that the aviaries with wetter manure are more appropriate to their development (BRUNO et al., 1993; STTAFORD; BAY, 1987; LOPES et al., 2008). Oliveira et al. (2018) observed that the interval of removal of the waste, your humidity and the presence of other ectoparasites in shelters were associated with the high or moderate risk index for the presence of diptera.

The presence of the beetle $A$. diaperinus (Coleoptera: Tenebrionidae) (Panzer, 1797) $(\mathrm{OR}=$ $0.15,95 \% \mathrm{CI}=0.067$ to $0.36, \mathrm{p}=0.000$ ), also known as 'Lesser Mealworm', was classified as a protective factor against infestation. Thus, in the layer chicken houses where this beetle is found the chance of occurrence of Chrysomya spp. is 6.66 times lower. These results are probably due to the predator behavior of this beetle about Diptera's eggs and larvaes. Santoro et al. (2010) suggest that $A$. diaperinus and Carcinops troglodytes (Coleoptera: Histeridae) (Paykull, 1811) are predators of Diptera such as $M$. domestica and $C$. megacephala. GIANIZELLA (2000) notes that adults of Euspilotus modestus (Coleoptera: Histeridae) (Erichson, 1834) consume, every day, approximately 26 eggs of $C$. putoria.

Some regions of the state of Minas Gerais were characterized as protective regions, which have less chance of to present infestations by Chrysomya spp. (Table 2). The regional of Unaí had perfect success of the model, which indicates that all laying houses of this region showed infestation by these flies, which led to exclusion of this regional of the model. These results strongly suggest that this region has a high risk of infestation. These differences among regions can be attributed, for example, to climate variations and differences among poultry establishments not evaluated in the study. As Pinto-Coelho (2000) stated, other factors may influence the occurrence of these arthropods, such as food availability, space, ecological relationships, genetic components, social interaction and dispersal of each species.

\section{CONCLUSIONS}

Flies of the genus Chrysomya are frequent in layer poultry farms in Minas Gerais, requiring specific sanitary management. Some differences between the laying houses and other variables that were not evaluated in this study, as relative humidity, temperature and precipitation, are important in the epidemiology of infestations by Chrysomya species and should be evaluated in future surveys. High levels of humidity of poultry manure increase the chances of infestations, and it is recommendable avoid excessive humidity of manure, checking leaks in water pipes and drinking fountains.

The presence of the beetle A. diaperinus is a protective factor against infestation by Chrysomya spp. Therefore, the application of pesticides in poultry farms should avoid the total elimination of populations of this beetle, once that the lesser mealworm is important in biological control of these flies.

Some regions of the state had lower chances of infestations by Chrysomya spp. when compared 
to others regions. Some environmental, biological or management factors can evidence these results. Therefore, the study suggests the accomplishment of some management measures that could assist in decreasing the frequency of Chrysomya spp. in laying houses, such as constant monitoring of water leaks on manure, adequate composting of dead poultry and periodic removal of manure.

\section{ACKNOWLEDGMENTS}

The authors are grateful to Instituto Mineiro de Agropecuária (IMA) and farm owners for the visitation authorizations. We are indebted to $\mathrm{CNPq}$, FAPEMIG and CAPES for financial support and scholarships.

RESUMO: Aspectos relacionados à epidemiologia das infestações por dípteros do gênero Chrysomya foram estudados com o objetivo de determinar os fatores predisponentes para sua ocorrência em granjas comerciais de postura do estado de Minas Gerais, Brasil. Foi realizado um estudo observacional, analítico e seccional para verificar os principais determinantes epidemiológicos das infestações por Chrysomya spp. Foram visitadas 43 granjas avícolas em 2012 e dessas 13 (30,23\%) apresentaram infestação por Chrysomya putoria, 4 (9,30\%) por Chrysomya megacephala, $2(4,65 \%)$ por Chrysomya albiceps e em 2 granjas $(4,65 \%)$ não foi possível identificar as espécies de Chrysomya. A verificação dos determinantes epidemiológicos foi realizada utilizando modelos de regressão logística múltipla. Diferenças entre os núcleos das granjas avícolas e que não foram avaliadas neste estudo, apresentaram-se importantes na epidemiologia destas moscas (OR=5.05 95\% IC $=2.66$ a 9.58, $\mathrm{p}=0.000)$. Observou-se também que o aumento na umidade do esterco dos aviários aumenta as chances de ocorrência de infestações $(\mathrm{OR}=1.81,95 \% \mathrm{IC}=1.36$ a $2.40, \mathrm{p}=0.000)$. A presença de coleópteros popularmente conhecidos como "Cascudinhos", Alphitobius diaperinus $(\mathrm{OR}=0.15,95 \% \mathrm{IC}=0.067$ a $0.36, \mathrm{p}=$ 0.000), foi caracterizada como um fator protetor contra infestações, provavelmente devido ao comportamento predador deste coleóptero. Algumas regiões do estado apresentaram menores chances de ocorrência de infestações por Chrysomya spp. quando comparadas a outras regiões. Algumas medidas de manejo, como monitoramento constante de vazamentos de água no esterco, compostagem adequada de aves mortas e remoção periódica do esterco, poderiam auxiliar na diminuição da presença de Chrysomya spp. no interior dos galpões de postura.

PALAVRAS-CHAVE: Chrysomya putoria. Chrysomya megacephala. Chrysomya albiceps. Galinhas poedeiras. Manejo da cama de aviários. Determinantes epidemiológicos.

\section{REFERENCES}

AMAT, E.; VÉLEZ, M. C.; WOLFF, M. Clave ilustrada para la identificación de los géneros y las especies de califóridos (Diptera: Calliphoridae) de Colombia. Caldasia, v.30, p.231-244, 2008.

AVANCINI, R. M. P.; SILVEIRA, G. A. R. Age Structure and Abundance in Populations of Muscoid Flies from a Poultry Facility in Southeast Brazil. Memórias do Instituto Oswaldo Cruz, v. 95, n. 2, p. 259-264, 2000. http://dx.doi.org/10.1590/S0074-02762000000200022

AXTELL, R. C.; ARENDS, J. J. Ecology and management of arthropod pests of poultry. Annual Review of Entomology, v. 35, p. 101-126, 1990. https://doi.org/10.1146/annurev.en.35.010190.000533

BARREIRO, C.; ALBANO, H.; SILVA, J.; TEIXEIRA, P. Role of flies as vectors of foodborne pathogens in rural areas. ISRN Microbiology Hindawi, v. 2013. http://dx.doi.org/10.1155/2013/718780

BLAAK, H.; HAMIDJAJA, R. A.; VAN HOEK, A. H.; DE HEER, L.; DE RODA HUSMAN, A. M.; SCHETS, F. M. Detection of extended-spectrum beta-lactamase (ESBL)-producing Escherichia coli on flies at poultry farms. Applied and Environmental Microbiology, v. 80, n. 1, p. 239-246, 2014. https://doi.org/10.1128/AEM.02616-13 
BORGES, M. A. Z. Flutuação populacional de dípteros muscóides (Diptera: Muscomorpha), parasitóides e foréticos predadores Igarapé, MG. 2006. 103f. Tese (Doutorado em Ciência Animal) - Curso de Pós-graduação em Ciência Animal, Universidade Federal de Minas Gerais, Belo Horizonte, 2006.

BRUNO, T. V.; GUIMARÃES, J. H.; SANTOS, A. M. M.; TUCCI, E. C. Moscas sinantrópicas (Diptera) e seus predadores que se criam em esterco de aves poedeiras confinadas no Estado de São Paulo, Brasil. Revista Brasileira de Entomologia, v. 37, n. 3, p .577-590, 1993.

CARVALHO, C. J. B; RIBEIRO, P. B. Chave de identificação das espécies de Calliphoridae (Diptera) do sul do Brasil. Revista Brasileira de Parasitologia Veterinária, v. 9, n. 2, p. 169-173, 2000.

CUNHA L. M. Aspectos epidemiológicos relacionados à ocorrência de ácaros hematófagos em granjas comerciais de postura no Estado de Minas Gerais e avaliação de armadilhas para captura de Dermanyssus gallinae (Acari: Dermanyssidae) (De Geer, 1778). 2013. 96f. Tese (Doutorado em Ciência Animal) - Curso de Pós-graduação em Ciência Animal, Universidade Federal de Minas Gerais, Belo Horizonte, 2013.

DOHOO, I.; MARTIN, W.; STRYHN, H. Veterinary epidemiologic research. Charlottetown Canada: Atlantic Veterinary College; 2003.

GIANIZELLA, S. L. Observação em laboratório de ciclos biológicos e hábitos de duas espécies de Histeridae (Coleoptera): Euspilotus modestus (Erichson) e Carcinops troglodites (Paykull) e sua possível utilização no controle biológico de dípteros sinantrópicos em granja de aves poedeiras. 2000. 136f. Tese (Doutorado em Parasitoligia) - Instituto de Biologia da Universidade Estadual de Campinas, Campinas, 2000.

GUIMARÃES, J. H.; TUCCI, E. C.; BARROS-BATTESTI, D. M. Ectoparasitos de importância veterinária. São Paulo: Plêiade FAPESP; 2001.

IBGE - Instituto Brasileiro de Geografia e Estatística. Disponível em:

<https://cidades.ibge.gov.br/brasil/mg/panorama> Acesso em: 25 mar. 2019

INSTRUÇÃO NORMATIVA No 56, DE 4 DE DEZEMBRO DE 2007- Disponível em:

$<$ http://sistemasweb.agricultura.gov.br/sislegis/action/detalhaAto.do?method=visualizarAtoPortalMapa\&chave $=1152449158>$ Acesso em: 20 abr. 2016.

LANDIS, J. R.; KOCH, G. G. The measurement of observer agreement for categorical data. Biometrics, v. 33, n. 1, p. 159-174, 1977. https://doi.org/10.2307/2529310

LOPES, W. D. Z.; COSTA, F. H.; LOPES, W. C. Z.; BALIEIRO, J. C. C.; SOARES, V. E.; PRADO, A. P. Artrópodes Associados ao Excremento de Aves Poedeiras. Neotropical Entomology, v. 36, n. 4, p. 597-604, 2007. http://dx.doi.org/10.1590/S1519-566X2007000400020

LOPES, W. D. Z.; COSTA, F. H.; LOPES, W. C. Z.; BALIEIRO, J. C. C.; SOARES, V. E.; PRADO, A. P. Abundância e Sazonalidade de Dípteros (Insecta) em granja avícola da região nordeste do estado de São Paulo, Brasil. Revista Brasileira de Parasitologia Veterinária, v. 17, n. 1, p. 21-27, 2008.

http://dx.doi.org/10.1590/S1984-29612008000100005

MCALPINE, J. F.; PETERSON, B. V.; SHEWELL, G. E.; TESKEY, H. J.; VOCKEROTH, J. R.; WOOD, D. M. Manual of Nearctic Diptera. Ottawa: Research Branch Agriculture Canada; 1987.

MONTEIRO, M. R.; PRADO, A. P. Ocorrência de Trichopria sp. (Hymenoptera: Diapriidae) Atacando Pupas de Chrysomya putoria (Wiedemann) (Diptera: Calliphoridae) na Granja. Anais da Sociedade Entomológica do Brasil, v. 29, n. 1, p. 159-167, 2000. http://dx.doi.org/10.1590/S0301-80592000000100020

NUORTEVA, P. Synanthropy of blow-flies (Diptera, Calliphoridae) in Finland. Annales Entomologica Fennica, v. 25, p. 1-49, 1963. 
PECK, J. H.; ANDERSON, J. R. Influence of poultry manure removal schedules on various diptera larval and selected arthropod predators. Journal of Economic Entomology, v. 63, n. 1, p. 69-71, 1970.

https://doi.org/10.1093/jee/63.1.82

OLIVEIRA, T. M.; TEIXEIRA, C. M.; ARAUJO, I. L.; REZENDE, L. C. CUNHA, L. M.; FILHO, R. P. L. C.; SORAIA ARAÚJO DINIZ, S. A.; SILVA, M. X. Caracterização epidemiológica e avaliação de risco associados à presença da ordem Diptera em granjas de postura. Acta Scientiae Veterinariae, v. 46, n. 1563, 2018. https://doi.org/10.22456/1679-9216.83468

PINTO-COELHO, R. M. Fundamentos de Ecologia. Porto Alegre: Artmed; 2000.

PRADO, A. P. Controle das principais espécies de moscas em áreas urbanas. In: Palestra, Universidade de Campinas (UNICAMP) Instituto de Biologia Departamento de Parasitologia Campinas/SP, Biológico 2003; 65(1/2): 95-97.

RAFAEL, J. A.; MELO, G. A. R.; CARVALHO, C. J. B.; CASARI, A. S.; CONSTATINO, R. Insetos do Brasil: diversidade e Taxonomia. Ribeirão Preto SP: Holos Editora; 2012.

REZENDE, L. C.; Aspectos epidemiológicos de Megninia spp. (Acari: Analgidae) e malófagos (Insecta: Phthiraptera) na avicultura de postura de Minas Gerais (2012). 2014. 81f. Dissertação (Mestrado em Ciência Animal) - Curso de Pós-graduação em Ciência Animal, Universidade Federal de Minas Gerais, Belo Horizonte, 2014.

REZENDE, L. C.; CUNHA, L. M.; MARTINS, N. R. S.; TEIXEIRA, C. M.; OLIVEIRA, P. R. Epidemiology of Megninia spp. in laying flocks from the State of Minas Gerais, Brazil. Revista Brasileira de Parasitologia Veterinária, v. 24, n. 2, p. 198-203, 2015. http://dx.doi.org/10.1590/S1984-29612015027

REZENDE, L. C.; OLIVEIRA, T. M.; TEIXEIRA, C. M.; PASTRANA, M. E. O.; OLIVEIRA, P. R.; MARTINS, N. R. S.; CUNHA, L. M. Occurrence and epidemiology of Fannia spp. (Diptera: Fanniidae) in laying poultry farms in state of Minas Gerais, Brazil. Brazilian Journal of Poultry Science, v. 20, n. 3, p. 419424, 2018. http://dx.doi.org/10.1590/1806-9061-2017-0595

SANTORO, P. H.; NEVES, P. M. O. J.; ALEXANDRE, T. M.; GAVAGUCHI, A. S.; ALVES, L. F. A. Carcinops troglodytes (Erichson) (Coleoptera: Histeridae) predando larvas de Alphitobius diaperinus (Panzer) (Coleoptera: Tenebrionidae) em aviários. Neotropical Entomology, v. 39, n. 5, p. 831-832, 2010. http://dx.doi.org/10.1590/S1519-566X2010000500026

STAFFORD, K. C.; BAY, D. E. Dispersion and association of house fly, Musca domestica (Diptera: Muscidae), larvae and both sexes of Macrocheles muscadomestica (Acari: Macrochelidae) in response to poultry manure moisture, temperature, and accumulation. Environmental Entomology, v. 16, n. 2, p. 159-164, 1987. https://doi.org/10.1093/ee/16.1.159

TRIPLEHORN, C. A.; NORMAN, F. J. Estudo dos insetos. São Paulo: Cengage learning; 2015.

YANG, Q. E.; TANSAWAI, U.; ANDREY, D. O.; WANG, S.; YANGWANG, Y.; SANDS, K. et al. Environmental dissemination of $m c r-1$ positive Enterobacteriaceae by Chrysomya spp. (common blowfly): An increasing public health risk. Environment International, v. 122, p. 281-290, 2019.

https://doi.org/10.1016/j.envint.2018.11.021 